DOI https://doi.org/10.31470/2616-6275-2020-4-165-183

\author{
Андрій Бойко-Гагарін \\ кандидат історичних наук \\ Старший зберігач фондів відділу \\ «Музей Грошей» \\ Управління зв'язків з громадськістю та \\ фінансової обізнаності \\ Департаменту комунікацій \\ Національного Банку України \\ (Київ, Україна)
}

\author{
Dr. Andrii Boiko-Haharin \\ $\mathrm{PhD}$, Senior treasures keeper of the \\ «Museum of Money» \\ Sector of Public Relations and Financial \\ Awareness \\ Department of Communications \\ The National Bank of Ukraine \\ (Kiyv, Ukraine)
}

boiko.gagarin@gmail.com

ORCID: https://orcid.org/0000-0003-4610-3665

Researcher ID: N-6985-2017

\title{
ПІДРОБКИ РОСІЙСЬКИХ ГРОШЕЙ КІНЦЯ ХІХ - ПОЧАТКУ ХХ СТОЛІТТЯ У ЗІБРАННІ НАЦІОНАЛЬНОГО МУЗЕЮ ІСТОРІЇ УКРАЇНИ
}

\section{THE RUSSIAN MONEY COUNTERFEITS OF THE END OF XIX - THE BEGINNING OF THE XX CENT. IN THE COLLECTION OF THE NATIONAL MUSEUM OF UKRAINIAN HISTORY}

\section{Анотація.}

Необхідність вивчення аспекту фальшивомонетництва у межах нумізматики довгий час залишалася поза межами защікавлень науковців, вивчення изього питання також не було включено до числа перспективних проблем розвитку вітчизняної нумізматики.

Мета статmі полягає у введенні до наукового обігу підробок обігових монет часів Російської імперії, щзо зберігаються у колекиї сектору нумізматики, фалеристики, медальєрики та боністики Національного музею історії Украӥни (НМІУ), з окресленням історї̈ їх надходження та спробою локалізувати виготовлення таких монет.

Методологія дослідження. Наукове пізнання прочесів фальшивомонетництва не зводиться лише до переліку фактів виявлення підробок, щзо характерно для більшості працьь, присвячених иій темі. У процесі вивчення зразків тогочасних підробок, щзо зберігаються у музейній колекиії, використано ілюстративний, метрологічний та іконографічний методи. Як додаткові дані для всебічного дослідження фальшивих монет використано їх фотографування та вимірювання технічних параметрів, редагування фотографій у графічних редакторах та встановлення відповідності їх характеристик з описами в історичних джерелах - матеріалах дорадянських газет та історичних apхівах.

Наукова новизна полягає у тому, щзо більшість використаних у дослідженні джерел (матеріали карних справ із фондів історичних архівів, повідомлення дорадянських газет та екземпляри із зібрань фондів музею) вводяться до наукового обігу вперше.

Висновки. У колекиії Національного музею історії України нами виявлено 9 тогочасних підробок монет Російської імперії. Серед них 2 екземпляри монет вартістю10 коп., 1 екземпляр - 15 коп., два зразки підробок монети вартістю 20 коп., щзо виготовлені за зразком монет одного року (1878 р.), 50 копійок зразка 1901 р. і три 
фальшивих рублі зразка найбільш поширених років карбування оригінальних монет, 1899, 1901 та 1912 рр. Монети виготовлено як із олов'яного сплаву, щуо зовні мав імітувати колір срібла, так $і$ з нанесенням покриття. Одна монета виготовлена шляхом спаювання двох пластин.

Джерело надходження більше ніж половини монет невідоме, у фондовій документації зафіксовано отримання двох монет від приватних осіб, в тому числі у складі колекиії, а також иляхом передачі з Фінвідділу МВС СРСР. Можна припустити, щзо наявні в колекиї НМІУ фальсифікати монет походять із знахідок на Київщині та могли виготовлятись на теренах колишньої Київської губернії, адже про факти виявлення подібних підробок нам відомо з низки архівних кримінальних справ та повідомлень зі шпальт газет дорадянського часу.

Вважаємо, щзо дану категорію монет (так само, як $і$ банкнот та грошових сурогатів), а саме старі приватні підробки, щуо виготовлялися з метою їх збуту для задоволення власних потреб, у музейних колекиіях як державних, так і приватних установ необхідно виносити в окрему групу зберігання. Відповідних коректив також потребують і наявні в музеях інструкиії з обліку.

Перспективою подальших досліджень ми визначаємо виявлення, вивчення та введення до наукового обігу тогочасних фальсифікатів грошових знаків з інших музеїв Украӥни. Сподіваємось, ия публікація спонукатиме музейних прачівників до співпраці у сфері наукового опрацювання серед матеріалів музейних зібрань і тогочасних підробок.

Ключові слова: фальшивомонетництво, Російська імперія, музейні колекиї, джерела вивчення, Наџіональний музей історії України.

\section{Summary.}

The need of study of the aspect of money counterfeiting in Russian empire for a long time went beyond the views of numismatists.

The aim of the study in this article is to introduce into the scientific circulation of the counterfeits of the circulation coins of the time of the Russian Empire, which are stored in the collection of the sector of numismatics, phaleristics, medallions and bonistics of the National Museum of Ukrainian history (NMUH), indicating the history of their receipt and the attempt to localize their manufacture.

We were able to detect the previous study and publish the examples of the forgeries of coins and paper money of that time from the museum collections of the Odessa Archaeological Museum, the Museum of Kyiv History, the National historic-ethnographic reservation of "Pereyaslav», as well as in the collections of foreign museums: the Hermitage Museum in St. Petersburg, the National museum of history of the Republic of Belarus in Minsk and the Museum of the National Bank of Lithuania in Vilnius.

Research methodology. Scientific knowledge of the processes of counterfeiting is not limited only to the list of facts of counterfeiting, which is typical of most works devoted to this topic. Illustrative, metrological, and iconographic methods were used in the process of studying the specimens of the fakes of the time in the museum collection. Additional data were used to thoroughly investigate counterfeit coins by photographing them and measuring technical parameters, editing photos in graphic editors by $P C$, and matching descriptions in historical sources - materials from pre-Soviet newspapers and the criminal cases in the historical archives.

The scientific novelty is that most of the sources used in the study (punitive cases material from historical archives, reports from the old newspapers, and items from museum collections) are published for the first time. 
Museums are collecting, storing, studying, and promoting the antiquities. By collecting materials that comprehensively cover the history of the region, in order to promote the features of everyday life in the historic area, used objects of everyday life, museums regularly collect evidences of the historical past for its further study and display. In this article we have introduced into scientific circulation the contemporary counterfeits of the coins made on the prototype of circulating money of the Russian Empire, which are stored in the collections of the Numismatics, Phaleristics, Medallion and Bonistics sector of the National Museum of Ukrainian History.

Anyway the counterfeits for the loss of the cash circulation are rare examples among the museum collections. Unfortunately, most of the counterfeits studied at that time in the museum collections did not record the locations and circumstances of the counterfeit, inventory and entry books with information about the origin of these coins in the museum collection indicate that most of these coins were transferred from private collections. So it already makes impossible to add these coins to the topography of the finds and to draw additional conclusions about these specimens, etc. In most museums, the overwhelming absence of specimens of contemporary coin counterfeiting is caused not only by the destruction of the latter after the investigation, but also by an imperfect strategy of collecting in museums, based solely on replenishment through free transfer to permanent storage by private persons and objects to the property of the state with their further transfer to the museum.

Fake securities were no less popular than making counterfeit money. Technologically, the degree of complexity was even slightly smaller, and the potential amounts of the non-legal profit could be obtained from counterfeit bills sometimes reached impressive levels, as documented in the sources. A sample of 50 rubles promissory note paper was stored in the NMUH collection, which could be used by counterfeiters to forge paper money - the credit bills.

With the rising costs of World War I, the need for money increased rapidly, prompting the Government of the Russian Empire to significantly increase the issue of paper money that completely filled the money supply. In order to save time and production resources, banknotes with a nominal value of 1, 3, 5 and 10 rubles were assigned the same, much shorter than the previous issue, number and letter series printed on the banknotes. It is a matter of course that such banknotes instantly caused distrust among the public, as the existence of identical serial numbers is often characteristic of counterfeits. The NMUH collection contains the samples of Russian credit bills with identical series and numbers issued during the First World War and, of course, that are the authentic government money.

At that time, the counterfeits of the coins, the prototype for which were circulating coins of the Russian Empire, were stored in the NMUH in the amount of 9 pieces, all of which can be dated from the end of the XIX - the beginning of XX century. Some of the counterfeits belong to the storage group "AE», which unites the copper coins. Part of the forgeries belongs to the group of storage of silver coins «AR», because they came as a part of a single complex collection, or the fact of making these samples from precious metals was revealed by acid testing and determination of the composition of the metal on the test stone.

The Conclusions. In the collection of the National Museum of Ukrainian History we discovered 9 old contemporary coins of the Russian Empire. Among them are 2 copies of 10 kopeck coins, 1 piece of 15 kopecks, two samples of counterfeits of 20 kopecks coins made by the prototype of the coins minted in 1878, as well as one-half and three counterfeit rubles: the sample of the most common years of minting of the original coins in 1899, 1901 and 1912. The coins were made of tin alloy, which was supposed to mimic the color of silver and the coating. One coin is made by soldering of the two plates. 
The source of the receipts of more than half of the coins is unknown, the funds documentation records the receipt of two coins from individuals, including a part of the collection, as well as a transfer from the Finance Department of the Ministry of Internal Affairs of the USSR. It can be assumed that the forged collections of the NMUH coins originate from the findings of the Kyiv region and could have been produced in the territory of the former Kyiv province of Russian empire, since the facts of the detection of such counterfeits are known to us from a number of archival criminal cases and reports from the pre-Soviet newspapers.

We believe that such a category of coins (as well as banknotes and money surrogates), as old private counterfeits made for the purpose of damage losses to money circulation and fraud, must be brought to a separate storage group in museum collections of both public and private institutions. Appropriate adjustments are also required in the museum's accounting instructions.

From the prospects of further research we see the detection, study and introduction into the scientific circulation of the contemporary counterfeit banknotes and coins from other museums in Ukraine and former Russian empire modern independent states. We hope that this publication will encourage museum staff to collaborate on the scientific elaboration of counterfeits of the materials of the museum collections.

Keywords: counterfeiting, Russian Empire, museum collections, sources of study, National Museum of Ukrainian History.

Постановка проблеми. Необхідність вивчення аспекту фальшивомонетництва у межах нумізматики довгий час залишалася поза межами зацікавлень науковців, вивчення цього питання також не було включено до числа перспективних проблем розвитку вітчизняної нумізматики.

Академіком Віктором Коцуром визначено актуальні напрями та організаційні засади сучасних методологічних досліджень в галузі нумізматики. Дослідник справедливо окреслив ряд завдань: «...визначення основних зразків монетних підробок, вивчення технології виготовлення фальсифікатів, визначення регіональних особливостей виявлення фальшивих монет в якості одиничних знахідок чи скарбових комплексів» ${ }^{1}$, вказуючи таким чином на важливість та актуальність наукового дослідження різних аспектів історії фальшивомонетництва на території України. Разом з тим саме В. Коцур установив основи вивчення скарбознавства ${ }^{2}$, де необхідність уведення до наукового обігу нумізматичних матеріалів, пов’ язаних з історією фальшивомонетництва, також визначено як актуальний напрям наукових студій.

Аналіз останніх досліджень і публікацій. Цікавість до вивчення української нумізматики виникла ще у XIX ст. В імперську добу тематика підробки грошей головним чином вивчалася 3 юридичної точки зору. Одним із перших дослідників процесів покарання винних у фальшивомонетництві був професор Університету Св. Володимира В. Сокольський ${ }^{3}$. Учений проаналізував зміни у ставленні влади до сутності фальшивомонетництва як злочину проти держави, а також інтерпретації його як образи владної особи, як суспільно шкідливої діяльності, що виражалася у шахрайстві та зловживанні довірою.

\footnotetext{
Коцур В. П. Актуальні напрямки та організаційні засади сучасних досліджень середньовічної нумізматики в Україні. Наукові записки з української історії: Збірник наукових статей. Вип. 33. Переяслав-Хмельницький, 2013. С. 5.

Коцур В. П. Історіографія українського скарбознавства. Український Нумізматичний Щорічник. № 1. Київ-Переяслав-ХмельницькийКропивницький, 2017. С. 15-33.

Сокольский В. О нарушениях уставов монетных. Историко-юридическое исследование. Киев: Университетская типография, 1873.210 с.
} 
Перший 3 детальних описів виявлених підробок монет для обігу здійснено В. Данилевичем. Дослідник детально описував усі відмінні риси малюнка та недотримання технології у виготовленні фальшивих монет 10 та 20 коп. зразка 1899 р., виявлених ним у м. Юр'єві (сучасне м. Тарту в Естонії- Б-Г.)ํ. Василь Данилевич також указує на високу актуальність уведення до наукового обігу монет з приватних та музейних колекцій, підкреслюючи, що не введення цих матеріалів до наукового обігу становить основну причину недосконалого вивчення питань нумізматики Російської імперії².

Відомим українським ученим М. Котляром було проаналізовано стан та перспективи розвитку української нумізматики на сер. XX ст., з визначенням іiї «другого народження» зі зростанням кількості відомих скарбів та монет, здатності нумізматики до вирішення складних питань вітчизняної історії ${ }^{3}$ Учений також підкреслив вагому роль нумізматики як допоміжної (спеціальної) історичної дисципліни, яка становить частину загальноісторичного джерелознавства. У своїх ранніх публікаціях Микола Котляр бачив основні напрямки розвитку вітчизняної нумізматики у розширенні джерельної бази, поглибленні методологічних основ, теоретичному осмисленні предмету та завдань нумізматики як науки, а також посилення іiі ролі у процесі наукового вивчення на загал ${ }^{4}$.

Внесок у розвиток вивчення фальшування монет здійснено також А. БойкомГагаріним ${ }^{5}$, ним досліджено іноземні фінансові інтервенції у військовий час ${ }^{6}$, технології виготовлення підробок ${ }^{7}$, уведено до наукового обігу газетні ${ }^{8}$ та архівні джерела ${ }^{9}$. Зразки тогочасних фальсифікатів монет та паперових грошових знаків нам удалось виявити, вивчити та опублікувати 3 музейних зібрань Одеського археологічного музею ${ }^{10}$, Музею iсторії м. Києва ${ }^{11}$, HIE3 «Переяслав» ${ }^{12}$, а також із колекцій закордонних музеїв, а саме: польського Національного музею у Варшаві ${ }^{13}$, російського Державного Ермітажу ${ }^{14}$, білоруського Національного музею історії Республіки Білорусь ${ }^{15}$, литовського Музею Національного Банку Литви ${ }^{16}$.

IP НБУВ. Фонд ХХІХ. Особовий архівний фонд Василя Юхимовича Данилевича. Справа № 67. Арк. 3-6.

Данилевич В. Е. Случайные заметки в области новейшей русской нумизматики. Юрьев: Тип. К. Маттисена в Юрьеве, 1898. С. 1-2.

3 Котляр М. Ф. Стан і перспективи розвитку української нумізматики. Український історичний журнал. № 11. Київ, 1965. С. 26.

${ }^{4}$ Котляр М. Ф. Допоміжні історичні дисципліни на сучасному етапі розвитку історичної науки. Український історичний журнал. № 2 (155). Київ, 1974. С. 81-84

Бойко-Гагарин А. С. Половина матрицы фальшивомонетчика для подделки рубля Николая II Романова. Банкаўскі веснік. № 12 [653]. Мінск, Снежань 2017. С. 57-58.

${ }^{6}$ Орлик С. В., Бойко-Гагарін А. С. Фальшивомонетництво в Україні в роки Першої світової війни. Український нумізматичний щорічник. № 1. Переяслав-Хмельницький, 2017. С. 143-164.

Бойко-Гагарин А. С. (2019). Половина матриці для підробки 1 копійки Російської імперії кін. ХІХ - початку ХX ст. Конотопські читання. № 10. C. $68-72$.

${ }^{8}$ Бойко-Гагарін А. С. Газетна періодика як джерело вивчення процесів фальшування монет та банкнот в кінці XIX - початку XX століття. Український нумізматичний щорічник. № 2. Переяслав-Хмельницький, 2018. С. 132-149.

9 Бойко-Гагарін А. С. Характеристика джерел вивчення фальшивих монет та банкнот в грошовому обігу України в імперську добу (17951917). Соціум. Документ. Комунікація. № 8. Серія: Історичні науки. Переяслав-Хмельницький: ФОП Домбровська Я.М. 2019. С. 55-75. DOI: 10.31470/2518-7600-2019-8-55-75.

${ }^{10}$ Бойко-Гагарін А. С., Кокоржицька Т. М. Орти Сигізмунда ІІІ Ваза в колекції Одеського археологічного музею. Записки отдела нумизматики и торевтики Одесского археологического музея. № III. Одесса: «Ибрис», 2017. С. 107-119. Також. Бойко-Гагарин А., Корпусова И. Монетновагові зливки гривні та їх тогочасні підробки з колекції Одеського археологічного музею. Записки отдела нумизматики и торевтики Одесского археологического музея. № III. Одесса: Ибрис, 2017. С. 120-132.

11 Бойко-Гагарин А. С., Трифонова Н. А. Фальшивые монеты ушедшей епохи в собрании Музея истории Киева. Нові дослідження пам'яток козацької доби в Україні: Зб.наук.праць, Вип. 23. Київ, 2014. С. 218-221.

12 Бойко-Гагарін А. С., Кузьменко А. В. Фальшиві монети часів Сигізмунда III Ваза у колекції НІЕЗ «Переяслав». Зб. наук. ст. «Переяславський літопис». Випуск 9. Переяслав-Хмельницький, 2016. С. 186-188.

13 Бойко-Гагарін А. С. Тогочасні підробки монет Російської імперії у зібранні Національного музею у Варшаві. Речі і образи: матеріали конференції «Спеціальні історичні дисципліни в контексті «речового» та «візуального» поворотів європейської гуманітаристики» (4 жовтня 2019 р., м. Київ). Відпов. ред. Ольга Ковалевська; упоряд. Світлана Блащук, Геннадій Боряк, Ольга Ковалевська. Київ : Ін-т історії України Національної академії наук України, 2020. С. 110-115.

${ }^{14}$ Kotsur V., Boiko-Gagarin A. Napoleon russian forged assignations in Naddniprianshchyna (over Dnipro land). East European historical bulletin. Issue 11. Drohobych, 2019. P. 66-77.

5 Бойко-Гагарин А. С. Подделки денежных знаков XIX - XX века в собрании Национального исторического музея Республики Беларусь. Банковский вестник. № 12 (677). Минск: Национальный банк Республики Беларусь, 2019. С. 53-55.

16 Бойко-Гагарин А., Рузас В. О необычной подделке медной копейки Русского царства из коллекции Музея денег Банка Литвы. Тэзісы дакладаў Трэція навуковыя чытанні памяці прафесара Валянціна Навумавіча Рябцэвіча (1934-2008). Мінск, 16-18 мая 2018 г. Мінск, 2018. С. 56-57. 
Частину тогочасних підробок із зібрання Національного музею історії України опубліковано В. Орликом ${ }^{1}$, В. Коцуром ${ }^{2}$, Г. Козубовським ${ }^{3}$, 3. Зразюк ${ }^{4}$ а також фальсифікатів за прототипом монет Османської ${ }^{5}$ та Російської 6 імперій та кредитових білетів Української Народної Республіки введено у науковий обіг А. Бойком-Гагаріним спільно з О. Родіоновою7 ${ }^{7}$ Відомим ученим О. Реєнтом у процесі аналізу спільних рис спеціальних галузей історичної науки та історичного краєзнавства надано високу оцінку ефективності роботи Національного музею історії України, Одеського археологічного музею, Львівського історичного музею, а також НIЕЗ «Переяслав» ${ }^{8}$.

Стан і тенденції подальшого розвитку історії державних фінансів Російської імперії визначено професором В. Орликом ${ }^{9}$. Учений вдало визначив методологію ${ }^{10}$, особливості фіскальної політики ${ }^{11}$, джерельну базу дослідження ${ }^{12}$, а також особливості державного фінансового управління ${ }^{13}$. Внесок у дослідження особливостей грошового обігу ${ }^{14}$, фінансової політики Російської імперії ${ }^{15}$ та підробки грошей ${ }^{16}$ у роки Першої Світової війни здійснено С. Орлик. Зародження та розвиток історії банківської системи Російської імперії встановлено М. Орликом ${ }^{17}$.

Теоретико-методологічні основи дослідження визначено 3 орієнтацією на класифікацію Я. Калакури, який поділив методи джерелознавчого дослідження на загальнонаукові, історичні та джерелознавчі. У свою чергу, до загальноісторичних методів віднесено: аналітичний, синтетичний, логічний, ретроспективний, математичний та ілюстративний. До історичних методів: історико-порівняльний, хронологічний, синхроністичний, діахронічний та типологічний. До джерелознавчих методів належать: критичний, евристичний, метрологічний, археографічний, іконографічний та палеографічний ${ }^{18}$.

${ }^{1}$ Орлик В., Бойко-Гагарін А. Монети, передані з Всеукраїнського Історичного Музею імені Тараса Шевченка до Державного Банку СРСР в 1933-1934 pp. Studia I materialy z Miedzynarodowej Konferencji Numizmatycznej. «Utracone kolekcje numizmatyczne». 6-7 grudnia 2018 r. Warszawa: Zamek Krolewski w Warszawie, 2019. S. 225-237.

${ }^{2}$ Kotsur V., Boiko-Gagarin A. Napoleon russian forged assignations in Naddniprianshchyna (over Dnipro land). East European historical bulletin. Issue 11. Drohobych, 2019. P. 66-77. DOI: 10.24919/2519-058x.11.170701

3 Козубовский Г. А. О медных гривнах. Тезисы докладов и сообщений «Тринадцатая всероссийская нумизматическая конференция». 11-15 апреля 2005 г. Москва, 2005. С. 104.

4 Зразюк 3. А. Монеты-подделки из клада, найденного в 2000 году в с. Лелюховка Новосанжарского района Полтавской области. Тезисы докладов и сообщений «Четырнадцатая всероссийская нумизматическая конференция». Санкт-Петербург, 2007. С. 124-125.

5 Бойко-Гагарін А. С. Тогочасні підробки ісламських монет із колекції В. Гріньковського у зібранні Національного музею історії України. Збірник наукових праць «Науковий вісник Національного музею історії України». Випуск II. Київ, 2017. С. $187-195$.

6 Бойко-Гагарін А. С. Позолочений червінець Катерини II із зібрання НМІУ. Нумізматика і Фалеристика. № 1. Київ, 2019. С. 14-15.

Бойко-Гагарін А., Родіонова О. Тогочасні підробки 100 карбованців 1917 року у колекції НМІУ. Нумізматика і фалеристика. № 3. Київ, 2018. C. $22-25$.

8 Реєнт О. Нумізматика в системі історичного краєзнавства. Тези доповідей III Міжнародної науково-практичної конференції «Актуальні проблеми нумізматики у системі спеціальних галузей історичної науки». 5-6 листопада 2015 р. Кіровоград-Київ-Переяслав-Хмельницький, 2015. C. 10.

${ }^{9}$ Орлик В. М. Державні фінанси Російської імперії першої половини ХІХ ст.: стан та основні тенденції. Науковий вісник Ізмаїльського державного гуманітарного університету. Вип. 30. Ізмаїл, 2011. С. 96-108.

10 Орлик В.М. До питання методології досліджень проблем економічної історії Російської імперії. Проблеми історії України ХІХ - початку XX ст. Вип. XVIII. 2011. Київ. С.59-64. Його ж. Орлик В. М. Методологічні аспекти дослідження проблем податкової політики в українських губерніях Російської імперії у першій половині ХІХ ст. Український історичний журнал. 2008. № 5. С. 187-195. Його ж. Орлик В.М., Орлик С.В. Теоретико-методологічні та джерелознавчі проблеми економічної історії України. Універсум історії та археології. 2019. Том. 2 (27) Вип 2. Дніпро. С. 5-27.

11 Орлик В. М. Єгор Канкрін і фіскальна політика Російської імперії в Правобережній Україні в другій чверті ХІХ ст. Спеціальні історичні дисципліни: питання теорії та методики. 2006. № 13. С. 97-110. Його ж. Орлик В. М. Податкова політика Російської імперії в Україні в дореформений період: монографія. Кіровоград: Імекс-ЛТД, 2007. 631 с.

12 Орлик В. М. Дожовтнева фінансово-правова література як джерело до вивчення проблем фінансової політики уряду Російської імперії кінця XVIII початку XX ст. Історія науки і біографістика. 2010. No 2. URL: http://www.nbuv.gov.ua/e-journals/INB/2010-2/10_orlyk.pdf

${ }^{13}$ Орлик В. М. Казенні палати в системі фінансового управління Російської імперії в кінці XVIII - у XIX ст. (на матеріалах Київської губернії). Український історичний журнал, 2003. № 2 (449). С. 66-73.

${ }^{14}$ Орлик С. В. Українське повітове місто і велика війна: продовольчі проблеми та ріст цін. Проблеми української історії. Вип. 23. Київ, 2015. C. $114-133$.

15 Орлик, С. В. (2018) Фінансова політика російського уряду на окупованих територіях Галичини і Буковини в період Першої світової війни (1914-1917 рр.): монографія. Біла Церква: Вид. Пшонківський О. В., 716 с.

16 Орлик С. В., Бойко-Гагарін А. С. Фальшивомонетництво в Україні в роки Першої світової війни. Український нумізматичний щорічник. Переяслав-Хмельницький, 2017. № 1. С. 143-164. Ї̈ ж. Орлик С. В. (2018) Российские фальшивые кредитные билеты в Галиции в годы Первой мировой войны. Банкаускі Веснік. Минск, (2). 51-54.

17 Орлик М. В. (2018). Зародження банківської кредитної системи в Російській імперії та Наддніпрянській Україні у другій половині ХVII I- на початку XIX ст. Центральноукраїнський науковий вісник. Економічні науки. Вип.1 (43). С. 75-82. Його ж. Орлик М. В. (2019). Розвиток банківського кредитування в Наддніпрянській Україні у другій половині XIX - на початку XX ст. Економічний вісник університету: зб. наук праць. Переяслав-Хмельницький. Вип. 42. С. 217-223.

${ }^{18}$ Калакура Я. С., Войцехівська І. Н. Історичне джерелознавство. Підручник для студентів історичних спеціальностей вищих навчальних закладів. Київ: Либідь, 2002. С. 120. 
Наукове пізнання процесів фальшивомонетництва не зводиться лише до переліку фактів виявлення підробок, що характерно для більшості праць, присвячених цій темі попередниками. Поглиблене вивчення передбачає концептуальне та теоретичне осмислення, потребує використання численних наукових методів та різнопланових джерел. Тому важливу складову процесу наукових досліджень становить вивчення іiі методології. У процесі вивчення зразків тогочасних підробок, що зберігаються у найбільшій музейній колекції нашої Держави, використано ілюстративний, метрологічний та іконографічний методи. Як додаткові дані для всебічного дослідження фальшивих монет використано їх фотографування та вимірювання технічних параметрів, редагування фотографій у графічних редакторах додатками на ПК для порівняння зразків з іншими підробками та встановлення їх відповідності з описами в історичних джерелах матеріалах дорадянських газет та історичних архівах.

Формулювання цілей статті. У цій статті ми маємо на меті увести до наукового обігу зразки тогочасних підробок обігових монет часів Російської імперії, що зберігаються у колекції сектору нумізматики, фалеристики, медальєрики та боністики Національного музею історії України (НМІУ), з’ясувати історію їх надходження та спробою локалізувати виготовлення цих монет.

Виклад основного матеріалу дослідження. Безумовно, одне із найбільш цінних та інформативних джерел у нумізматичних дослідженнях складають самі монети. У дослідженні історії грошового обігу С. Орлик ${ }^{1}$ визначені основними нумізматичні та боністичні джерела. Збором, зберіганням, вивченням та популяризацією старожитностей займаються музеї. Збираючи матеріали, які всебічно висвітлюють історію регіону, презентують предмети побуту, що використовувалися в той чи інший період, музеї опрацьовують їх для подальшого вивчення та експонування а також 3 метою популяризації особливостей побутування населення в історичній місцевості. У цій роботі ми висвітлимо та введемо у науковий обіг тогочасні підробки монет, що виготовлялися за прототипом обігових грошей Російської імперії і які зберігаються у колекції сектору нумізматики, фалеристики, медальєрики та боністики Національного музею історії України (НМІУ). Необхідність грунтовного вивчення музейних колекцій підкреслював у своїх працях В. Орлик, досліджуючи монети Тевтонського Ордену у Пруссії та його відділення у Лівонії з указаного зібрання².

Виходячи із досліджених нами документів та матеріалів, які викладені у програмах комплектування фондів музеїв, можна встановити, що у фокусі нумізматичного напрямку формування колекції старі підробки для збитку грошового обігу також не зазначаються. У зібранні рукописних документів НМІУ зберігається машинопис доповіді на з'їзді «Просвіт» від 23.IX.1917 р. під назвою «Програма місияевого / повітового, районного / музея» ${ }^{3}$, що аргументує важливість збору історичних пам'яток а також надає список видів старожитностей основного пріоритету комплектування місцевих музеїв, серед яких монети не зазначено взагалі. Натомість, 30 грудня 1922 р. Міністерством Народної Освіти для Архівної Комісії було видано спеціальну «Інструкцію з перебрання історичних матеріалів» ${ }^{4}$, відповідно до якої пріоритет збору предметів музейного значення фокусувався навколо документів дипломатичного характеру й таких, що свідчать про боротьбу народу за незалежність України.

\footnotetext{
Орлик С. В. Нумізматичні та боністичні джерела дослідження історії грошового обігу в Галичині й Буковині під час російської окупації в роки Першої Світової війни. Актуальні проблеми нумізматики у системі спеціальних галузей історичної науки: тези доповідей V міжнародної науково-практичної конференції, 21-22 червня 2018 р. Меджибіж - Переяслав-Хмельницький - Кропивницький - Київ, 2018. С. 139-142.

2 Орлик В. Топографія знахідок в Україні монет держави Тевтонського ордену в Пруссії та ії Лівонського відділення (зведені відомості по областях). Український нумізматичний щорічник. Вип. 1. Переяслав-Хмельницький. 2017. С. 37-74.

${ }^{3}$ НМІУ. Програма місцевого / повітового, районного / музея. 1917 рік. Інв. № РД-10510.

${ }^{4}$ ЦДАГО. Фонд 3696. Міністерство закордонних справ Української Народної Республіки, м. Київ. Опис 2. Справа 138. Арк. 133-135. Матеріали поширені на сторінці в архіву у соціальній мережі «Facebook».
} 
Вагомим джерелом дослідження обраної теми стали матеріали музеїв - музейні предмети та документи ${ }^{1}$. Окрему групу серед музейних предметів завжди складають паперові гроші (бони) та монети. Фальшиві монети є досить рідкісними зразками серед музейних предметів. На жаль, у процесі фіксації більшості вивчених тогочасних підробок у музейних зібраннях не було зафіксовано місць та обставин знахідки підробок. Інвентарні книги та книги вступу знахідок з інформацією про походження цих монет у музейній колекції свідчать про передачу більшості цих монет із колекцій приватних осіб, що на сьогодні вже унеможливлює додавання цих монет у топографію знахідок та можливості здійснення додаткових висновків щодо цих екземплярів тощо. Також переважна відсутність у більшості музеїв зразків тогочасних підробок монет спричинена не лише знищенням останніх після проведення слідства, а також і недосконалою стратегією колекціонування ${ }^{2}$ у музеях, що базована виключно на поповненні за рахунок безоплатного передавання знахідок на постійне зберігання від приватних осіб та предметів, затриманих митними органами та оберненими у майно держави 3 їх подальшою передачею у музеї.

Тогочасні фальсифікати монет, зразком для імітації яких стали обігові монети Російської імперії, збережено у НМІУ у кількості 9 екземплярів, що датуються кін. XIX - поч. XX ст. Частина фальсифікатів віднесена до групи зберігання «AЕ», яка об’єднує мідні монети. Інша частина віднесена до групи зберігання срібних монет «AR», адже вони надійшли у складі єдиного комплексного зібрання.

Дві підробки імітують 10 коп. монети зразка 1905 (Рис. 1) та 1906 р. (Рис. 2). Фальшиві 10 коп. зразка 1906 р. надійшли до музею від громадянина Ф. А. Болдарева у 1954 р. Монету виготовлено з недорогоцінного металу із залишками слідів подальшого покриття металом білого кольору. Натомість фальшиві 10 коп. зразка 1905 р. виготовлено iз недорогоцінного металу сірого кольору, що мав, за задумом фальсифікатора, імітувати виготовлення підробки зі срібла.

Слід зазначити, що в документах того часу фактів виготовлення підробок «гривеників» та монет, номіналом 15 коп., нами знайдено відносно невелику кількість. 25 лютого 1909 р. Київський окружний суд виніс вирок козаку з с. Хацьки Переяславського повіту Полтавської губ. - Мойсею Андрежву Богдану, що виготовляв фальшиві рублі, а також монети вартістю 20 та 10 коп. у буд. № 29 по вул. Троїцькій у м. Києві ${ }^{3}$. Того ж року виготовлені за допомогою карбування олов'яні монети дрібного номіналу було виявлено у домі селянина Прокофія Голуба, що мешкав у с. Сторожове Полтавської губ. - 11 шт. підроблених монет номіналом 15 коп., 5 монет - номіналом 10 коп. та олов'яні заготовки.які й було вилучено. Всі члени родини: дружина Олександра Голубова, а також селянин того ж села Діомид Бузина займались фальшивомонетництвом ${ }^{4}$. На жаль, точних місць та обставин виявлення досліджених монет у книгах надходження детально не зафіксовано, можна лише припустити, що вказані монети могли виготовлятись у тодішній Київській губернії. Причиною малої чисельності свідчень про фальсифікацію цього монетного номіналу ми бачимо у більшій вигоді підробляти монети середніх номіналів - 20 та 50 коп. Найчастіше за зразок для підробки використовували монету номіналом 20 коп. 5 березня 1877 р. у м. Ковелі було затримано мешканців м. Брест-Литовського, слюсарних справ майстрів, євреїв Лейбу Овсей Хаймовича Леблевського та Арона Лейбова Лукіна, що були ув'язнені за підробку та збут

Ковальчук С.І. Музей як джерельна база в профільних і музеєзнавчих дослідженнях. Збірник наукових праць «Могилянські читання 2015». До 90-річчя Національного Києво-Печерського історико-культурного заповідника. Київ, 2016. С. 421.

2 Шелудякова Н. «Колекційні студії» в контексті матеріального повороту в гуманітаристиці. Ейдос. Випуск 6. Київ, 2011/2012. С. 470.

3 ДАКО. Фонд 7. Київське тюремне відділення. Опис 3. Справа 679. Справа про виконання вироку Київського окружного суду над Мойсеєм Богдановим (звинувачуваним у підробці грошей). Рік 1909. Арк. 2.

${ }^{4}$ Обнаружение фабрики фальшивых монет. Полтавские Ведомости. № 367. 8 апреля. Полтава, 1909. С. 2. 
фальшивих 20 коп. монет ${ }^{1}$. Після виявлення з-посеред контрабандних товарів фальшивих 20 коп. зразка 1880 р. у їх власника -селянина с. Пукляки (нині Чемеровецький р-н., Хмельницька обл. - Б-Г.) - Артемія Мацишина було проведено обшук, у ході якого: «/.../ ніяких знарядь, які могли б слугувати для підробки дзвінкої монети знайдено не було»². 21 червня 1893 р. у м. Гранів (суч. Гайсинський р-н., Вінницька обл. - Б.Г.) учителем народного училища Бенедиктом Бесядовським при обміні церковних грошей серед мідних 5-копійчаних монет було виявлено фальшиву монету номіналом 20 коп., яка касирами Гайсинського повітового казначейства була описана як: «/.../ звичайної форми та вигляду з гарно відтиснутим орлом та решіткою 1883 р. ${ }^{3}$, колір монети жовтий, внизу решітки видимі літери Д.П.Б.» ${ }^{4}$. Імовірно, фальшивомонетником або укладальником документів архівної справи було допущено помилку у позначенні монетного двору у м. Санкт-Петербурзі, що вказувався на монеті літерами «С.П.Б.».

У фондовій колекції НМІУ збережено два екземпляри фальсифікатів 20 коп. монет, які виготовлені за зразком 1878 р. (Рис. 4-5). Одну з фальшивих «двогривенних» монет виготовлено шляхом припаювання двох срібних пластин (Рис. 4), другу підробку виготовлено більш поширеним методом - карбуванням заготовки із недорогоцінного металу та нанесенням покриття, залишки якого присутні на зразку (Рис. 5).

Наступний екземпляр нумізматичної збірки музею з числа підробок російських монет - монета вортістю 50 коп. зразка 1901 р., отримана у подарунок від громадянина на прізвище Берг у 1972 р. (Рис. 6). Підробку виготовлено зі сплаву металу сірого кольору, що деякий час зовні нагадував срібло.

Восени 1907 р. у м. Києві набула гучного резонансу справа про викриття фальшивомонетника Андрія Коноваленка, що підробляв монети номіналом 50 коп. на Деміївці. 13 жовтня 1907 р. у Коноваленка вилучено приладдя для фальсифікації монет та мідний сплав, з якого він виготовляв заготовки, все разом передане на експертизу. Експертами було встановлено, що виявлене на Деміївці обладнання придатне для спроб фальшування монети 513 жовтня газета «Киевлянин» уточнює, що затриманий був арештований на вул. Ново-Китаївська, а також його ім'я - Андрій. Разом із Андрієм Коноваленком були затримані ще 4 особи, вина яких не була доведена. У квартирі Коноваленка на Деміївці - вул. Велика Васильківська - у будинку його дядька Гоменюка було виявлено три гіпсові форми для виготовлення монет: дві призначалися для фальшування рублів та полтинників, третя - для полтинників та 20 коп. У печі чинами карної поліції було виявлено банку зі ртуттю, а також різні рідини, порошки та інструменти. На момент затримання злочинця «фабрика» Андрія Коноваленка не працювала, але огляд форм дав змогу встановити, що вони дійсно були у використанні. Коноваленко за фахом був слюсарем, але останній рік перекваліфікувався на майстра незаконного виготовлення монет, попрацювавши до того ще офіціантом у кафе на вул. Великій Васильківській, буд. 36. Нечистим перед законом виявився і дядько Коноваленка, який був невдовзі затриманий i переданий до суду за скоєння нападу 3 метою пограбування, його племінник Андрій Коноваленко крім фальшивомонетництва також займався розбоєм.

ЦДІАК. Фонд 442. Канцелярія Київського військового, Подільського та Волинського Генерал-Губернатора. Опис 56. Справа 329. Про підробку міщанином м. Ковеля 20-копійчаних монет. Рік 1877. Арк. 90.

2 ДАХО. Фонд 281. Прокурор Кам'янець-Подільського окружного суду. Опис 1. Справа 3100. Про виявлення у селянина с. Пульково у Мацишиної П. фальшивої монети 25-копійчаного номіналу. Рік 1890. Арк. 28.

3 ДАХО. Фонд 281. Прокурор Кам’янець-Подільського окружного суду. Опис 1. Справа 3968. Про виявлення у вчителя с. Пчельно у Босядовського В. фальшивих монет номіналом 5 та 20 коп. Рік 1883. Арк. 11.

4 ДАХО. Фонд 281. Прокурор Кам'янець-Подільського окружного суду. Опис 1. Справа 163. Про виявлення у рядового солдата суднохідної дистанції Зелінського Л. фальшивого 5-рублевого білету. Рік 1880. Арк. 11.

${ }_{5}^{5}$ К обнаружению фабрики фальшивых монет на Демеевке. Киевлянин. № 284. 10 октября. Киев, 1907. С. 4.

${ }^{6}$ Фабрика фальшивых монет. Киевлянин. № 283. 13 октября. Киев, 1907. С. 3. 
Наявні у зібранні НМІУ і фальшиві рублеві монети. Фальшивий рубль зразка 1899 р. копіює монети одного з найбільш масових років карбування (Рис. 7). Фальсифікат виготовлено з жовтого металу, який протям часу свого побутування мав бути покритий гаром срібла чи олова. На гурті фальсифікату зловмисниками нанесено імітацію легенди, що містить численні відхилення від стилю зображення літер легенди гурту справжніх монет державного зразка. Інформацію про спроби нанесення імітації гуртів фальшивомонетниками також збережено у тогочасних джерелах. У 1907 р. у м. Києві, у квартирі Іуліянії Муравикової було виявлено майстерню по виготовленню монет, де окрім ливарних форм застосовувались напилки (що мали сліди білого металу), шматки пемзи, шматки сплаву білого металу, отруту у склянці, а також пристрій для нанесення насічок на гурт ${ }^{1}$.

Фальшивий рубль зразка 1901 р. (Рис. 8) має синьо-сірий відтінок, що вказує на імовірне його виготовлення всуціль із олова. Така практика застосовувалася фальшивомонетниками для досягнення схожості з оригіналом підробкою кольору, подібного до срібного. 11 листопада 1909 р. на головному залізничному вокзалі м. Києва було затримано Петра Соловйова 3 усіма необхідними для виготовлення фальсифікатів монет речовинами та приладдям: двома зливками олова вагою $3 / 4$ фунта, гіпсовою формою, а також зошитом із занотованими рецептами та тонкощами виготовлення підробок². Фальсифікація рублів також не була рідкістю. 22 жовтня 1907 р. у м. Києві 3 фальшивою 1-рублевою монетою було затримано Арсенія Пирогова, поліція констатувала, що виявлена підроблена монета була «місцевого виготовлення»³.

Інший олов'яний рубль зразка 1912 р. не міг бути виготовлений раніше від зазначеної на ньому дати (Рис. 9). Монета надійшла до музею у 1946 р. із фінансового відділу Міністерства Внутрішніх Справ СРСР. I хоча своєрідний сплеск активності фальшивомонетників у м. Києві спостерігаємо, за даними джерел, у 1912 р., можна також припустити, що згадану підробку було виготовлено під час «монетного голоду» часів Першої Світової війни. Серед виявлених у джерелах, а саме кримінальних справах архівів та публікаціях газет, ми не знаходимо інформації про факти підробки рублів за зразком цього року, проте в них зафіксовані спроби підробки монет інших номіналів у м. Києві. 20 березня 1912 р. керівнику київської поліції надійшов секретний циркуляр від губернатора О. Ф. Гірса щодо занепокоєння особливою канцелярією Міністерства Фінансів по кредитній частині стосовно частої появи у місті фальшивих кредитних білетів (особливо часто 5-рублевого номіналу) та обігової монети ${ }^{4}$. Наступного 1913 р. київський губернатор повідомляв про часту появу підробок кредитних білетів 25-рублевого номіналу зразка 1909 p. ${ }^{5}$ а також 5-рублевого номіналу з вимогою негайного повідомлення його про всі випадки виявлення та затримання підозрюваних у збуванні підробок грошей 6 .

17 лютого 1912 р. на ст. Предмостова Слобідка Остерського повіту Чернігівської губ. (територія сучасного Гідропарку у м. Києві - Б.Г.) затримано єврея Сруля Хаїмова Хайтіна, який намагався збути 2 фальшиві 20 коп. монети дрібного номіналу при купівлі тютюну у крамниці Наталії Артамонової. Після чого він був затриманий на базарі унтерофіцером Олександром Доліним та переданий судовому слідчому III дільниці

Фабрика фальшивых монет. Киевлянин. № 321. Киев, 1907. С. 3

Задержание фальшивомонетчика. Киевские Вести. № 288. 29 октября (11 ноября). Киев, 1909. С. 3.

Фальшиво-монетчик. Кіевлянин. № 294. Киев, 1907. С. 4.

${ }^{4}$ ЦДІАК. Фонд 274. Київське губернське жандармське управління, м. Київ. Опис. 1. Справа 3071. Повідомлення про появу в Києві підробок 5 рублів. Рік 1912. Арк. 65.

5 ЦДІАК. Фонд 278. Київське жандармське поліцейське управління залізниць, м. Київ. Опис 1. Справа 187. Циркуляр Департаменту поліції про розшук збувальників фальшивих кредитних білетів. Рік 1913. Арк. 208.

${ }^{6}$ ЦДІАК. Фонд 285. Фастівське відділення Київського жандармського поліцейського управління залізниць, ст. Фастів Київської губернії. Опис 1. Справа. 430. Циркуляри Київського губернатора про встановлення, припинення негласного нагляду поліції та висилання з Київської губернії різних осіб. Рік 1913. Арк. 33. 
по Остерському повіті Чернігівської губ., пропонувавши поліції за своє негайне звільнення 10 руб. ${ }^{1}$

Підробка цінних паперів була не менш популярною, аніж виготовлення фальшивих грошей. Технологічно ступінь складності був навіть дещо меншим, а потенційні незаконно отримувані таким чином суми інколи досягали вражаючих розмірів, що задокументовано у джерелах. Візьмемо для прикладу ситуацію з підробкою векселів. Нагадаємо, вексель - борговий документ суворо регламентованої форми, що засвідчує безумовне зобов'язання однієї особи сплатити певну суму грошей на користь іншої у вказаний термін. Виходячи з визначення поняття «вексель», знаходимо його спорідненість 3 паперовими банківськими білетами, що за умов існування розвинутої економічної системи закріплює за векселем функцію обігу. Тому виявлені нами факти підробки векселів заслуговують на окрему увагу. У зібранні НМІУ збережено зразок вексельного паперу на 50 руб., подібний до якого міг використовуватись фальшивомонетниками для фальсифікації паперових грошових знаків - кредитних білетів (Рис. 10).

Із зростанням витрат на ведення Першої Світової війни потреба у грошовій масі стрімко збільшувалась, що спонукало уряд Російської імперії до суттєвого збільшення емісії паперових грошей, які повністю заповнили сферу грошового обігу. Задля економії часу та виробничих ресурсів на банкнотах номінальною вартістю 1, 3, 5 та 10 руб. ставився однаковий, значно коротший за нанесений на банкнотах попередніх емісій, номер та літерна серія. Певна річ, що такі грошові знаки миттєво викликали недовіру серед населення, адже наявність однакових серійних номерів часто характерна для підроблених банкнот, коли фальсифікатори використовують для виробництва обмежену кількість кліше без застосування нумератора. 3 уведенням таких кредитних білетів в обіг виникла необхідність повідомити населення про те, що запроваджені кредитні білети законні засоби платежу та емітовані не приватними особами для завдання збитків населенню, а державою. Про це 29 жовтня 1916 р. досить детально повідомляє газета «Аккерманское Слово»: «В обігу останнім часом з’явились кредитні папірці з однаковими номерами серії та білетів, при чому номери цих серій незвично коротші. Особливо це спостерігалося в номерах серій від 1 до 100. Як виявляється, поява коротких №№ серії пояснюється прийнятим оберненим порядком випуску серій. Острах того, що білети із однаковими номерами підроблені - безпідставні, адже віднині просто прийнятий новий порядок випуску білетів - лише кредитні білети високого номіналу (10 р.б., 25 р. та т.п.) нумеруються кожен окремо, так званим методом «графування», цим же способом виконується і підпис касира. Що стосується білетів рублевого номіналу, то такі, зважаючи на посилення роботи казначейства по емісії білетів, було вирішено нумерувати друкарським способом, в цілях економії часу та праці. Тому і номери на білетах виявляються однаковими. Стосовно цього в офіційних джерелах вже було роз'яснення»². Через нерозуміння населенням причини появи таких грошей по всій Російській імперії були зафіксовані численні випадки відмови приймати в розрахунок грошові знаки 3 однаковими номерами серії та порядкового номеру, що супроводжувалося сутичками та участю поліції у вирішенні спірних питань ${ }^{3}$. У зібранні НМІУ збережено зразки російських кредитних білетів з ідентичними серіями та номерами, які були випущені в роки Першої Світової війни та, безумовно, належать до автентичних грошових одиниць державного зразка. (Рис. 11).

Цікавим видається питання обліку та зберігання тогочасних підробок монет у музейних колекціях. Виходячи з того, що облік предметів, виготолених із дорогоцінних ${ }^{1}$ ЦДІАК. Фонд 1439. Чернігівське губернське жандармське управління, м. Чернігів. Опис 1. Справа 1414. Про затримання на станції Предмостова Слобідка єврея. 1912 рік. Арк 79-80.

2 Кредитки с одинаковыми номерами. Аккерманское Слово. № 1453. Суббота, 29 октября. Аккерман, 1916. С. 3.

3 Рублевыя кредитки. Верхнеднепровский Земский Листок. № 29. пятница, 22 июля. Верхнеднепровск, 1916. С. 333. 
та недорогоцінних металів, ведеться у музеях окремо ${ }^{1}$, а переважна більшість фальшивих монет виготовлена 3 недорогоцінного металу лише 3 подальшим покриттям тонким шаром дорогоцінного, записи щодо отримання подібних монет ведуться в інвентарних книгах обліку монет з недорогоцінних металів. Ті ж підробки, які за результатами проведеної апробації містять срібло чи золото у своєму складі, обліковуються в основному фонді разом з оригінальними монетами, які містять дорогоцінний метал. Приватні старі підробки в окрему групу збергінання не виносяться. Вважаємо, що таку категорію монет (так само як і банкнот та грошових сурогатів), як старі приватні підробки, що виготовлялися окремими особами з метою їх збуту для задоволення власних потреб, необхідно виносити в окрему групу зберігання в музейних колекціях як державних, так і приватних установ. Відповідних коректив також вимагають і наявні в музеях інструкції з обліку.

Висновки дослідження. Дослідивши низку наукових нумізматичних праць попередників, ми встановили, що більшість відомих нумізматів не бачили вивчення цієї теми серед актуальних напрямків та не розглядали ії в організаційних засадах розвитку цієї галузі історії в імперську добу. Необхідність вивчення аспекту фальшивомонетництва довгий час виходило за межі поглядів нумізматів, дослідження цього питання також не було включено до перспективних напрямів розвитку вітчизняної нумізматики.

У працях радянських дослідників спостерігаємо низку неточностей, допущених через політичну заангажованість та відповідні вимоги часу. Загалом найчастіше в окрему групу виділено гроші, що з'явились у результаті фінансових диверсій іноземних держав і такі, які знецінились після поразки у політичній боротьбі окремих урядів та політичних утворень, оголошених фальшивими. Таким чином, практично серед радянських та сучасних дослідників тогочасні підробки, фактично, не виділені в окрему групу. Вважаємо, що тогочасні підробки грошових знаків, що незаконно виготовлялись 3 метою їх збуту населенню для отримання незаконного прибутку, цілком виправдано мають займати окреме місце у класифікації предметів нумізматики та боністики.

Вивчення обраної теми стало можливим завдяки комплексному дослідженню низки різнопланових джерел: речових, зображальних, поведінкових та писемних. Основним речовим джерелом у вивченні обраної теми стали збережені до нашого часу тогочасні підробки монет та банкнот, що зберігаються у музейних та приватних зібраннях, інколи містяться в архівних справах як речові докази.

У колекції Національного музею історії України нами виявлено 9 тогочасних підробок монет Російської імперії. Серед них 2 екземпляри монет вартістю 10 коп., 1 екземпляр - 15 коп., два зразки підробок монети вартістю 20 коп., що виготовлені за зразком монет одного року (1878р.), 50 копійок зразка 1901 р. і три фальшивих рублі зразка найбільш поширених років карбування оригінальних монет - 1899, 1901 та 1912 рр. Монети виготовлено як із олов'яного сплаву, що зовні мав імітувати колір срібла, так і $з$ нанесенням покриття. Одна монета виготовлена шляхом спаювання двох пластин.

Джерело надходження більше ніж половини монет невідоме, у фондовій документації зафіксовано отримання двох монет від приватних осіб, в тому числі у складі колекції, а також шляхом передачі з Фінвідділу МВС СРСР. Можна припустити, що наявні в колекції НМІУ фальсифікати монет походять із знахідок на Київщині та могли виготовлятися на теренах колишньої Київської губернії, адже про факти виявлення подібних підробок нам відомо з низки архівних кримінальних справ та повідомлень зі шпальт газет дорадянського часу.

Инструкция о порядке учета и хранения музейных ценностей из драгоценных металлов и драгоценных камней, находящихся в государственных музеях и культурно-просветительских учреждениях СССР (от 18 сентября 1975 г.). Москва, 1976. 52 с. 
Вважаємо, що дану категорію монет (так само, як і банкнот та грошових сурогатів), а саме старі приватні підробки, що виготовлялися з метою їх збуту для задоволення власних потреб, у музейних колекціях як державних, так і приватних установ необхідно виносити в окрему групу зберігання. Відповідних коректив також потребують і наявні в музеях інструкції з обліку.

Перспективою подальших досліджень ми бачимо виявлення, вивчення та введення до наукового обігу тогочасних фальсифікатів грошових знаків з інших музеїв України. Сподіваємось, ця публікація стане для музейних працівників спонукою до співпраці в руслі наукового опрацювання тогочасних підробок серед матеріалів музейних зібрань.

\section{Каталог}

\begin{tabular}{|c|c|c|c|}
\hline Іл-и̧ія & Ідентифікаиія & Інв. № & Походження \\
\hline Рис. 1. & $\begin{array}{l}\text { Російська імперія. Тогочасна підробка } \\
\text { монети } 10 \text { коп. зразка } 1905 \text { р. СПБ. А-Р. }\end{array}$ & Інв. № AR-17469 & \\
\hline Рис. 2. & $\begin{array}{l}\text { Російська імперія. Тогочасна підробка } \\
\text { монети } 10 \text { коп. зразка } 1906 \text { р. СПБ. Э-Б. }\end{array}$ & Інв. № AE-7907 & $\begin{array}{l}\text { Подарунок музею від } \\
\text { громадянина } \\
\text { Ф.А. Болдарева у } 1954 \text { p. }\end{array}$ \\
\hline Рис. 3. & $\begin{array}{l}\text { Російська імперія. Тогочасна підробка } \\
\text { монети } 15 \text { коп. зразка } 1888 \text { р. }\end{array}$ & Інв. № AR-9485 & \\
\hline Рис. 4. & $\begin{array}{l}\text { Російська імперія. Тогочасна підробка } \\
\text { монети } 20 \text { коп. зразка } 1878 \text { р. }\end{array}$ & Інв. № AR-11451 & \\
\hline Рис. 5. & $\begin{array}{l}\text { Російська імперія. Тогочасна підробка } \\
\text { монети } 20 \text { коп. зразка } 1878 \text { р. }\end{array}$ & Інв. № AR-14016 & \\
\hline Рис. 6. & $\begin{array}{l}\text { Російська імперія. Тогочасна підробка } \\
\text { монети } 50 \text { коп. зразка } 1901 \text { р. }\end{array}$ & Інв. № AE-11432 & $\begin{array}{l}\text { Подарунок музею від } \\
\text { громадянина Берка у } \\
\text { складі колекції у } 1972 \text { p. }\end{array}$ \\
\hline Рис. 7. & $\begin{array}{l}\text { Російська імперія. Тогочасна підробка } \\
\text { монети } 1 \text { рубль зразка } 1899 \text { р. }\end{array}$ & Інв. № AE-13459 & \\
\hline Рис. 8. & $\begin{array}{l}\text { Російська імперія. Тогочасна підробка } \\
\text { монети } 1 \text { рубль зразка } 1901 \text { р. }\end{array}$ & Інв. № AE-7901 & \\
\hline Рис. 9. & $\begin{array}{l}\text { Російська імперія. Тогочасна підробка } \\
\text { монети } 1 \text { рубль зразка } 1912 \text { р. }\end{array}$ & Інв. № AR-5999/3 & $\begin{array}{l}\text { Надходження до музею } \\
\text { від Фінансового відділу } \\
\text { МВС у } 1946 \text { p. }\end{array}$ \\
\hline Рис. 10. & $\begin{array}{l}\text { Російська імперія. Зразок вексельного } \\
\text { паперу } 50 \text { руб }\end{array}$ & Інв. № ПГЗ-818 & \\
\hline Рис. 11. & $\begin{array}{l}\text { Російська імперія. Кредитні білети } \\
\text { номіналом } 5 \text { руб зразка } 1909 \text { р. Серія УА-102 }\end{array}$ & $\begin{array}{l}\text { Iнв. } \\
\text { № ПГЗ-754/3-1-5 }\end{array}$ & \\
\hline
\end{tabular}

\section{REFERENCES}

Boiko-Haharin, A. \& Rodionova, O. (2018) Tohochasni pidrobky 100 karbovantsiv 1917 roku u kolektsii NMIU. [Old forgeries of the 100 Ukrainian karbovanets of 1917 in the NMUH collection]. Numizmatyka i falerystyka. 3. 22-25. [in Ukrainian].

Boiko-Haharin, A. S. \& Kokorzhytska, T. M. (2017) Orty Syhizmunda III Vazy v kolektsii Odeskoho arkheolohichnoho muzeiu. [The orts of Sigismund III Vasa in the collection of the Odessa Archaeological Museum]. Zapysky otdela numyzmatyky y torevtyky Odesskoho arkheolohycheskoho muzeia. 3. 107-119. [in Ukrainian]. 
Boiko-Haharin, A. S. \& Kuzmenko, A. V. (2016) Falshyvi monety chasiv Syhizmunda III Vaza u kolektsii NIEZ «Pereiaslav». [The counterfeit coins of Sigismund III Vasa in the collection of the NHER «Pereyaslav»]. Pereiaslavskyi litopys. 9. 186-188. [in Ukrainian].

Boiko-Haharin, A. S. (2017) Tohochasni pidrobky islamskykh monet iz kolektsii $V$. Hrinkovskoho u zibranni Natsionalnoho muzeiu istorii Ukrainy. [The counterfeits of the Islamic coins from V. Grinkowsky's collection of the National Museum of Ukrainian History]. Naukovyi visnyk Natsionalnoho muzeiu istorii Ukrainy. 2. 187-195. [in Ukrainian].

Boiko-Haharin, A. S. (2018) Hazetna periodyka yak dzherelo vyvchennia protsesiv falshuvannia monet ta banknot v kintsi XIX-pochatku XX stolittia. [The newspapers periodicals as the source of study of the process of counterfeiting coins and banknotes during the late XIX - the early XX centuries]. Ukrainskyi numizmatychnyi shchorichnyk. 2. 132-149. [in Ukrainian].

Boiko-Haharin, A. S. (2019) Kharakterystyka dzherel vyvchennia falshyvykh monet ta banknot $v$ hroshovomu obihu Ukrainy $v$ impersku dobu (1795-1917). [The characteristics of the sources of study of the counterfeit coins and banknotes in the monetary circulation of Ukraine during the imperial era (1795-1917)]. Sotsium. Dokument. Komunikatsiia. Seriia: Istorychni nauky. 8. 55-75. DOI: 10.31470/2518-7600-2019-8-55-75. [in Ukrainian].

Boiko-Haharin, A. S. (2019) Pozolochenyi chervinets Kateryny II iz zibrannia NMIU. [The gold platted chervinets of Catherine II from the collection of NMUH]. Numizmatyka $i$ Falerystyka. 1. 14-15. [in Ukrainian].

Boiko-Haharin, A. S. (2020) Tohochasni pidrobky monet Rosiiskoi imperii u zibranni Natsionalnoho muzeiu u Varshavi. Instytut istorii. [The old forgeries of the Russian Empire coins in the collection of the National Museum in Warsaw]. Abstract of papers. Rechi i obrazy: materialy konferentsii "Spetsialni istorychni dystsypliny v konteksti «rechovoho» ta «vizualnoho» povorotiv yevropeiskoi humanitarystyky. pp. 110-115. [in Ukrainian].

Boiko-Haharyn, A. \& Korpusova, I. (2017) Monetno-vahovi zlyvky hryvni ta yikh tohochasni pidrobky z kolektsii Odeskoho arkheolohichnoho muzeiu. [Coin-weight hryvnia ingots and their counterfeits from the collection of the Odessa Archaeological Museum]. Zapysky otdela numyzmatyky y torevtyky Odesskoho arkheolohycheskoho muzeia. 3. 120-132. [in Ukrainian].

Boiko-Haharyn, A. S. (2019). Polovyna matrytsi dlia pidrobky 1 kopiiky Rosiiskoi imperii kin. XIX-pochatku XX st. [Half of the matrix for fake 1 kopeck of the Russian Empire. XIX- early XX centuries]. Konotopski chytannia - Konotop reading, 10, 68-72 [in Ukrainian].

Bojko-Gagarin, A. \& Ruzas, V. (2018) O neobychnoj poddelke mednoj kopejki Russkogo carstva iz kollekcii Muzeja deneg Banka Litvy. [About the unusual fake copper kopeck of the Russian Tsardom from the collection of the Bank of Lithuania Money Museum]. Abstract of papers: Trjecija navukovyja chytanni pamjaci prafesara Valjancina Navumavicha Rjabcjevicha (1934-2008). Minsk, 16-18 maja 2018 g. pp. 56-57. [in Russian].

Bojko-Gagarin, A. S. \& Trifonova, N. A. (2014) Fal'shivye monety ushedshej epohiv sobranii Muzeja istorii Kieva. [The old forgery coins in the collection of the Museum of History of Kiev]. Novi doslidzhennja pam'jatok kozac'koï dobi v Ukraïni. 23. 218-221. [in Russian].

Bojko-Gagarin, A. S. (2019) Poddelki denezhnyh znakov XIX-XX veka v sobranii Nacional'nogo istoricheskogo muzeja Respubliki Belarus'. [Money counterfeits of the 19th20th centuries in the collection of the National Historical Museum of the Republic of Belarus]. Bankovskij vestnik. 12 (677). 53-55. [in Russian].

Boyko-Gagarin, A. S. (2017). Polovina matrytsy falshivomonetchika dlya poddelki rublya Nikolaya II Romanova [Half of the counterfeiter's mold to fake the ruble of Nikolai II Romanov]. Bankovskiy vestnik [The Banking Bulletin]. Minsk, 12 (653), 57-68 [in Russian]. 
Danilevich, V. E. (1898) Sluchajnye zametki v oblasti novejshej russkoj numizmatiki. [Random notes in the modern Russian numismatics]. Jur'ev: Tip. K. Mattisena v Jur'eve. [in Russian].

Kalakura, Ya. S. \& Voitsekhivska, I. N. (2002) Istorychne dzhereloznavstvo. Pidruchnyk dlia studentiv istorychnykh spetsialnostei vyshchykh navchalnykh zakladiv. [Historical sources of study. The textbook for students of historical specialties of the higher educational institutions]. Kyiv: Lybid. [in Ukrainian].

Kotliar, M. F. (1965) Stan i perspektyvy rozvytku ukrainskoi numizmatyky. [Status and prospects of the development of Ukrainian numismatics]. Ukrainskyi istorychnyi zhurnal. 11. 26. [in Ukrainian].

Kotliar, M. F. (1974) Dopomizhni istorychni dystsypliny na suchasnomu etapi rozvytku istorychnoi nauky. [Auxiliary historical disciplines at the present stage of development of the historical science]. Ukrainskyi istorychnyi zhurnal. 2 (155). 81-84. [in Ukrainian].

Kotsur, V. P. \& Boiko-Gagarin, A. S. (2019) Napoleon russian forged assignations in Naddniprianshchyna (over Dnipro land). East European historical bulletin. (11). 66-77. [in English].

Kotsur, V. P. (2013). Aktualni napriamy ta orhanizatsiini zasady suchasnykh doslidzhen serednovichnoi numizmatyky v Ukraini. [Current trends and organizational principles of the modern studies of medieval numismatics in Ukraine]. Naukovi zapysky z ukrainskoi istorii [The scientifical notes of the Ukrainian history]. (33), 3-8. [in Ukrainian].

Kotsur, V. P. (2017) Istoriohrafiia ukrainskoho skarboznavstva [The historiography of the Ukrainian treasurology]. Ukrainskyi Numizmatychnyi Shchorichnyk. 1. 15-33. [in Ukrainian].

Kovalchuk, Ye. I. (2016) Muzei yak dzherelna baza v profilnykh i muzeieznavchykh doslidzhenniakh. [Museums as a source base in profile and museology studies]. Mohylianski chytannia 2015. Do 90-richchia Natsionalnoho Kyievo-Pecherskoho istoryko-kulturnoho zapovidnyka. pp. 421. [in Ukrainian].

Kozubovskij, G. A. (2005) O mednyh grivnah. [About the copper gryvna ingots]. Abstract of papers. Trinadcataja vserossijskaja numizmaticheskaja konferencija. pp. 104. [in Russian].

Orlik, S. V. (2018) Rossijskie fal'shivye kreditnye bilety v Galicii v gody Pervoj mirovoj vojny [Russian fake credit bills in Galicia during the First World War]. Bankauski Vesnik, 2, 51-54. [in Russian].

Orlyk, M. V. (2018). Zarodzhennia bankivskoi kredytnoi systemy v Rosiiskii imperii ta Naddniprianskii Ukraini u druhii polovyni XVIII - na pochatku XIX st. [The genesis of the banking credit system in Russian Empire and over Dnirpo Ukraine during the second half of the XVIII - the beginning of the XIX cent.]. Tsentralnoukrainskyi naukovyi visnyk. Ekonomichni nauky - Central Ukrainian Scientific Bulletin. Economic sciences, 1 (43), 75-82 [in Ukrainian].

Orlyk, M. V. (2019). Rozvytok bankivskoho kredytuvannia v Naddniprianskii Ukraini u druhii polovyni XIX - na pochatku XX st. [The development of the bank lending in the over Dnipro Ukraine during the second half of the XIX - the early XX century.]. Ekonomichnyi visnyk universytetu. [The University Economic Bulletin]. Pereiaslav-Khmelnytskyi, 42, 217223 [in Ukrainian].

Orlyk, S. V. (2015) Ukrains'ke povitove misto i velyka vijna: prodovol'chi problemy ta rist $\sin$ [Ukrainian county town and the great war: the food problems and the increase of prices]. Problemy ukrains 'koi istorii. [The problems of the Ukrainian history]. (23), 114-133. Kyiv. [in Ukrainian].

Orlyk, S. V. (2018) Finansova polityka rosiiskoho uriadu na okupovanykh terytoriiakh Halychyny i Bukovyny v period Pershoi svitovoi viiny (1914-1917 rr.). [The financial policy of 
the Russian Government in the Occupied Territories of Galicia and Bukovina during the First World War (1914-1917)]. Bila Tserkva: Pshonkivskyi O. V., 716 c. [in Ukrainian].

Orlyk, S. V. (2018) Numizmatychni ta bonistychni dzherela doslidzhennia istorii hroshovoho obihu v Halychyni y Bukovyni pid chas rosiiskoi okupatsii v roky Pershoi Svitovoi viiny. [The numismatic and bonistic sources of study of the history of the money circulation in Galicia and Bukovina during the Russian Occupation in WWI]. Abstract of papers. Aktualni problemy numizmatyky u systemi spetsialnykh haluzei istorychnoi nauky. V mizhnarodna naukovo-praktychna konferentsiia, 21-22 chervnia 2018 r. Medzhybizh-PereiaslavKhmelnytskyi-Kropyvnytskyi-Kyiv, 2018. S. 139-142. [in Ukrainian].

Orlyk, S. V., Boiko-Haharin, A. S. (2017) Falshyvomonetnytstvo v Ukraini v roky Pershoi svitovoi viiny [Money counterfeiting in Ukraine during the WWI]. Ukrainskyi numizmatychnyi shchorichnyk [The Ukrainian Numismatic Annual], (1), 143-164. [in Ukrainian].

Orlyk, V. \& Boiko-Haharin, A. (2020) Monety, peredani z Vseukrainskoho Istorychnoho Muzeiu imeni Tarasa Shevchenka do Derzhavnoho Banku SRSR v 1933-1934 rr. [Coins transferred from the All-Ukrainian History Museum named after Taras Shevchenko to the State Bank of the USSR in 1933-1934.]. Abstract of papers. "Utracone kolekcje numizmatyczne». 67 grudnia 2018 r. Warszawa: Zamek Krolewski w Warszawie. pp. 225-237. [in Ukrainian].

Orlyk, V. (2006). Yehor Kankrin i fiskalna polityka Rosiiskoi imperii v Pravoberezhnii Ukraini v druhii chverti XIX st. [Yegor Kankrin and the fiscal policy of the Russian Empire in the Right-Bank Ukraine during the second quarter of the XIX century]. Spetsialni istorychni dystsypliny:pytannia teorii ta metodyky [Special Historical Disciplines: Theory and Methodology]. 13. Nat. akad. nauk Ukrainy, In-t istorii Ukrainy. 97-110. [in Ukrainian].

Orlyk, V. (2017) Topohrafiia znakhidok v Ukraini monet derzhavy Tevtonskoho ordenu $v$ Prussii ta yii Livonskoho viddilennia (zvedeni vidomosti po oblastiakh). [The toporgaphy of the finds of the Teutonic Order in Prussia and it's Livonian branch coins in Ukraine (general data through the regions)]. Ukrainskyi numizmatychnyi shchorichnyk, 1, 37-74. [in Ukrainian].

Orlyk, V. M. \& Orlyk, S. V. (2019) Teoretyko-metodolohichni ta dzhereloznavchi problemy ekonomichnoi istorii Ukrainy. [Theoretical-methodological and source problems of economic history of Ukraine]. Universum istorii ta arkheolohii. [Universum of history and archeology]. Vol. 2 (27). Ed. 2. Dnipro. 5-27. [in Ukrainian].

Orlyk, V. M. (2007). Podatkova polityka Rosiiskoi imperii v Ukraini v doreformenyi period: monohrafiia [The tax policy of the Russian Empire in Ukraine in pre-reform period: the monograph]. Kirovohrad: Imeks-LTD. [in Ukrainian].

Orlyk, V. M. (2008). Metodolohichni aspekty doslidzhennia problem podatkovoi polityky $v$ ukrainskykh huberniiakh Rosiiskoi imperii u pershii polovyni XIX st. [The methodological aspects of the study of tax policy issues in the Ukrainian provinces of the Russian Empire during the first half of the XIX century]. Ukrainskyi istorychnyi zhurnal [Ukrainian Historical Journal]. 5. 187-195. [in Ukrainian].

Orlyk, V. M. (2010). Dozhovtneva finansovo-pravova literatura yak dzherelo do vyvchennia problem finansovoi polityky uriadu Rosiiskoi imperii kintsia XVIII pochatku XX st. [The Prerevolutionary financial and law literature as the source of study of the problems of the Russian Empire government financial policy during the late 18th - the early 20th century]. Istoriia nauky i biohrafistyka [History of Science and Biography]. 2. Retrieved from http://www.nbuv.gov.ua/e-journals/INB/2010-2/10_orlyk.pdf [in Ukrainian].

Orlyk, V. M. (2011). Derzhavni finansy Rosiiskoi imperii pershoi polovyny XIX st.: stan ta osnovni tendentsii. [The state finances of the Russian Empire in the first half of the XIX century: the condition and main tendencies]. Naukovyi visnyk Izmailskoho derzhavnoho humanitarnoho universytetu, (30), 96-108. [in Ukrainian]. 
Orlyk, V. M. (2011). Do pytannia metodolohii doslidzhen problem ekonomichnoi istorii Rosiiskoi imperii [On the question of the methodology of the research on the problems of the Russian Empire economic history]. Problemy istorii Ukrainy XIX-pochatku XX st. [The problems of the History of Ukraine during the 19th and early 20th centuries]. 18. 59-64. [in Ukrainian].

Orlyk, V.M. (2003). Kazenni palaty v systemi finansovoho upravlinnya Rosiys'koyi imperiyi v kintsi XVIII - u XIX st. (na materialakh Kyyivs 'koyi huberniyi) [State chambers in the system of financial management of the Russian Empire at the end of XVIII - in the XIX century (on materials of the Kiev province)]. Ukrayins 'kyy istorychnyy zhurnal Ukrainian Historical Journal, 2, 66-73 [in Ukrainian].

Reient, O. (2015) Numizmatyka v systemi istorychnoho kraieznavstva. [Numismatics in the system of historical local history]. Abstract of papers. III Mizhnarodnoi naukovopraktychnoi konferentsii «Aktualni problemy numizmatyky u systemi spetsialnykh haluzei istorychnoi nauky». pp. 10. [in Ukrainian].

Sheludiakova, N. (2011-2012) «Kolektsiini studii»v konteksti materialnoho povorotu v humanitarystytsi. [«Collection Studios» in the Context of Material Turn in the Humanities]. Eidos. 6. 470. [in Ukrainian].

Sokol'skij, V. (1873) O narushenijah ustavov monetnyh. Istoriko-juridicheskoe issledovanie. [About the monetary charters violations. The historical and legal research]. Kiev: Universitetskaja tipografija. [in Russian].

Zrazjuk, Z. A. (2007) Monety-poddelki iz klada, najdennogo v 2000 godu v s Leljuhovka Novosanzharskogo rajona Poltavskoj oblasti. [Coin forgeries from the treasure excavated in 2000 near the village Lelyukhovka in the Novosanzharsky district of the Poltava region]. Abstract of papers. Chetyrnadcataja vserossijskaja numizmaticheskaja konferencija. pp. 124125. [in Russian].

\section{Ілюстрації}

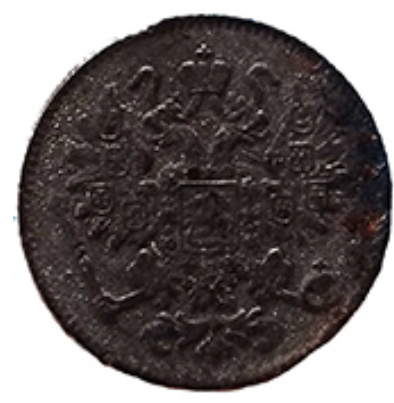

Pис. 1.
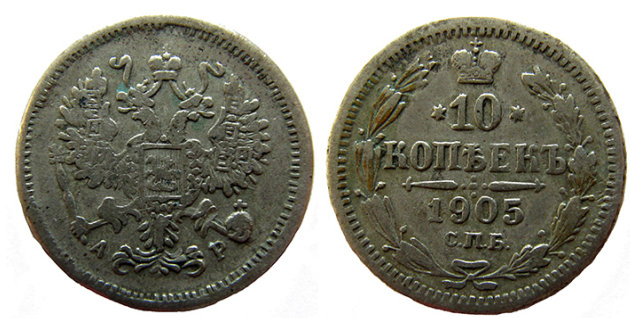

Pис. 2.
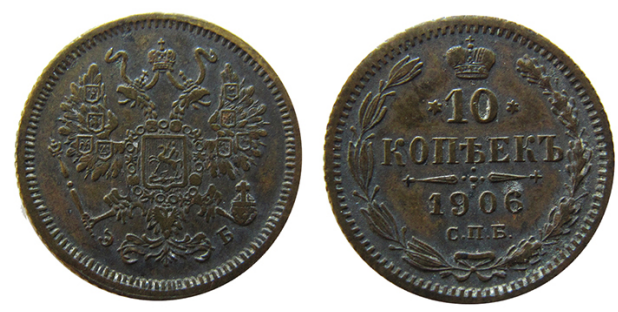

Pис. 3.

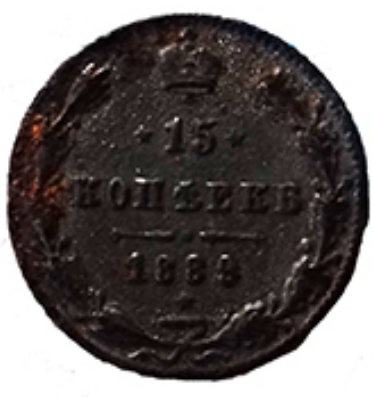

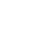


The Ukrainian Numismatic Annual. Issue 4
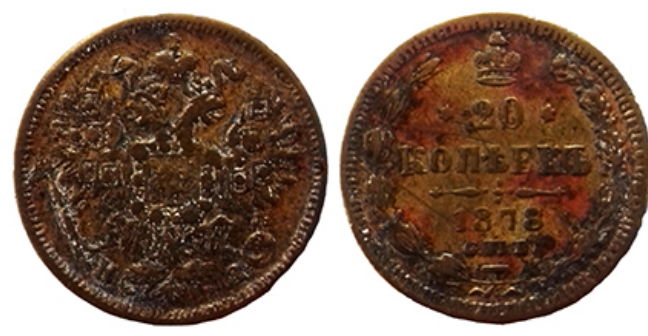

Рис. 5.
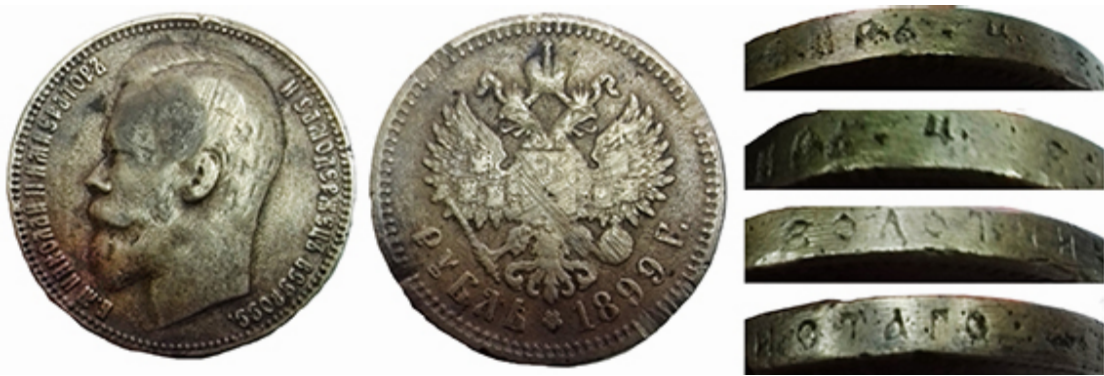

Рис. 7.
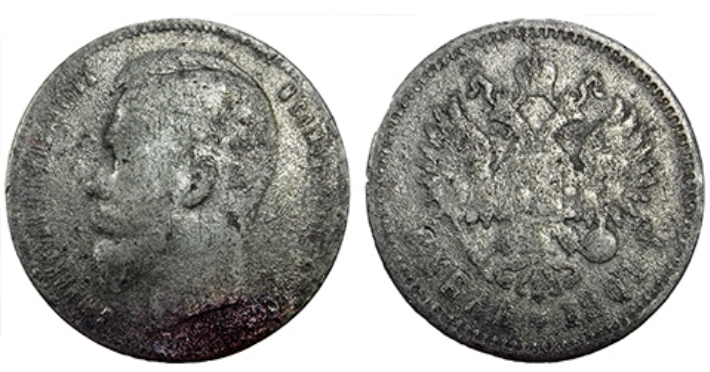

Рис. 8.
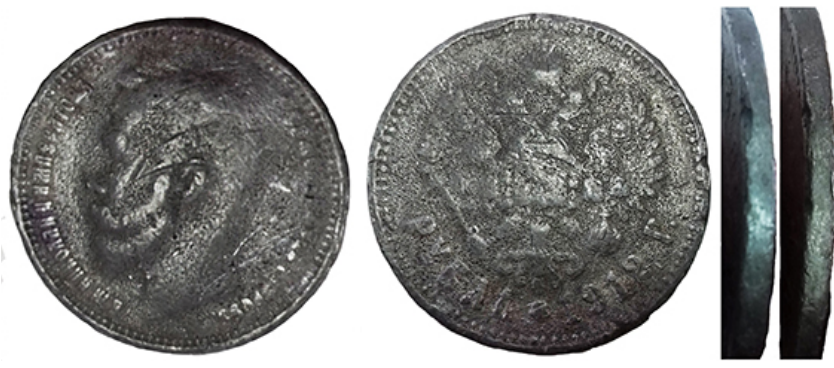

Рис. 9.

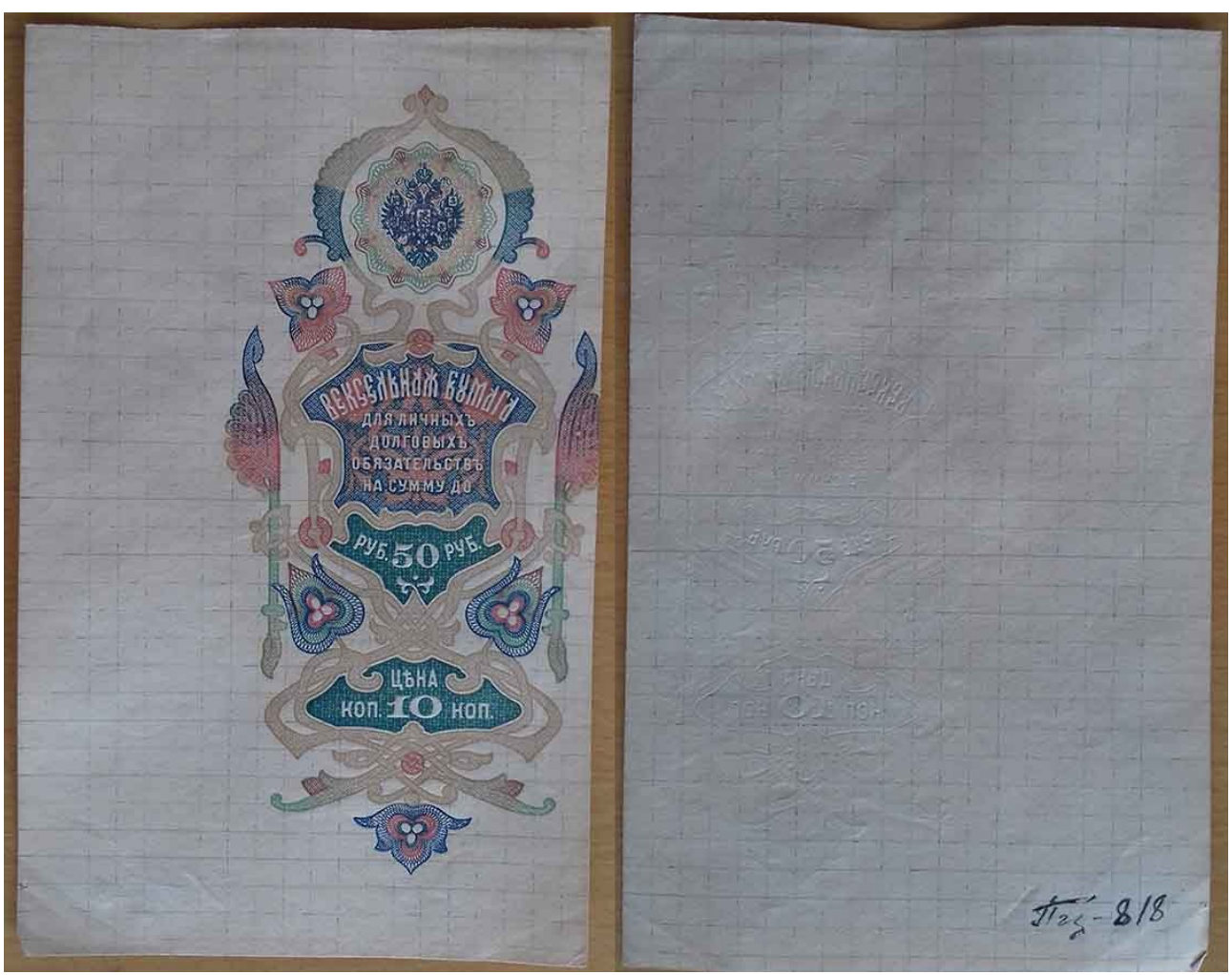

Рис. 10. 

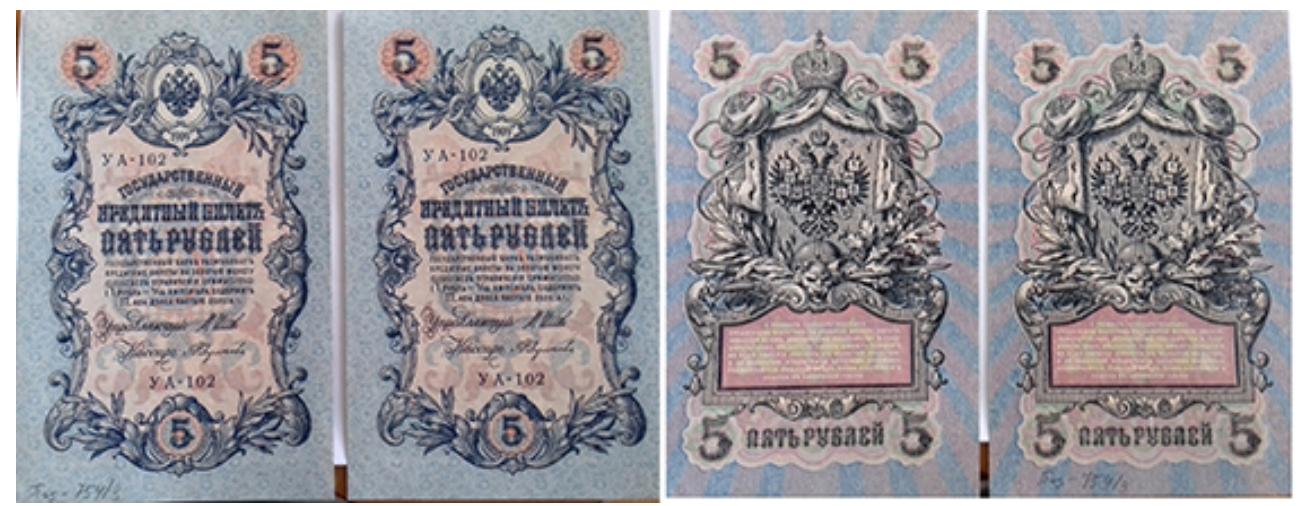

Рис. 11. 